\title{
The impact of selected macro variables on child labor in Indonesia
}

\author{
Shafinah Rahim, Fatin Nur Nadia Bakar \\ Faculty of Economics and Business, UNIMAS, Sarawak, Malaysia
}

\begin{tabular}{|c|c|}
\hline ARTICLE INFO & A B S T R A C T \\
\hline $\begin{array}{l}\text { Article history: } \\
\text { Received } 3 \text { September } 2017 \\
\text { Received in revised form } \\
11 \text { September } 2017 \\
\text { Accepted } 17 \text { September } 2017 \\
\text { Published } 30 \text { September } 2017\end{array}$ & $\begin{array}{l}\text { This study investigates the impact of government expenditure, household } \\
\text { expenditure and adult unemployment on child labour in Indonesia } \\
\text { between } 1985 \text { and } 2014 \text {. The data from the World Bank Indicators tested } \\
\text { using Johansen \&Juselius Cointegration (J\&J), Vector Error Correction } \\
\text { Model (VECM), Granger Causality, Generalized Variance } \\
\text { Decomposition (GVDCs) and Generalized Impulse Response Functions }\end{array}$ \\
\hline $\begin{array}{l}\text { Keywords: } \\
\text { Child labour } \\
\text { Education } \\
\text { Household income } \\
\text { Unemployment }\end{array}$ & $\begin{array}{l}\text { (GIRFs) show thatthere are long run and short run relationships between } \\
\text { the variables. Hence,the need to improve on policiesrelating to } \\
\text { encouraging children to attend school without affecting their family } \\
\text { income becomes critical. In addition household consumption pattern and } \\
\text { spending decisions may require adjustment with the support of the } \\
\text { authorities so as to assist the common man in prioritising their basic } \\
\text { development needs, especially education. }\end{array}$ \\
\hline
\end{tabular}

\section{Introduction}

Child labour remains a disturbing global issue affecting the developing countries most severely (Ranjan, 1990). A phenomenon that can be traced back to the $16^{\text {th }}$ century, in France, United Kingdom and Germany began at factories of cotton mills and glass and brick kilns. While inSweden and Norway, child labour was concentrated in the fishing and farming sectors. According to the latest report by the International Labour Orgnaization (ILO), approximately 211 million children aged between 5 to 15 are working all over the world. With 95\% centred in developing countries and $61 \%$ in Asia alone, of which Indonesia was the first to be officially identified.

Expectedly, there exists a strong link between poverty and child labour as empirically found by previous researches. Family financial pressures force a child as young as 10 years old to work as a maid for the well offs. Lower wages, flexible working hours and the ability to control these groups of workers create a constant oversupply of child labour. Studies by Manning, 2000; Morice, 1981; Sharma \&Mittar, 1990 conclude that child labour in Indonesia is focussed in the rural areas. The decreasing rate of child labour reversed automatically post 1997 crisis (Cameron, 2001). 